\title{
Antibody and DNA probes for detection of nitrite reductase in seawater
}

\author{
B. B. Ward, ${ }^{1 *}$ A. R. COCKCrofT ${ }^{1}$ and K. A. KILPATRICK ${ }^{2}$ \\ ${ }^{1}$ Institute of Marine Sciences, University of California, Santa Cruz, CA 95064, USA \\ ${ }^{2}$ Rosenstiel School of Marine and Atmospheric Sciences, University of Miami, Miami, FL 33149, USA
}

(Received 10 November 1992; revised 4 March 1993; accepted 17 March 1993)

\begin{abstract}
A polyclonal antiserum was produced by immunization with nitrite reductase (NiR) purified from Pseudomonas stutzeri (ATCC 14405) and tested for specificity among known denitrifying strains. The antiserum was nearly strain-specific, identifying NiR only in some, but not all, other $\boldsymbol{P}$. stutzeri strains. Denitrifying isolates from water column and sediment environments were also screened; several isolates from an intertidal microbial mat reacted with the NiR antiserum. Activity assays for NiR in polyacrylamide gels demonstrated that strains with apparently very similar NiR proteins did not react with the antiserum. These results imply that the NiR protein is more variable even among closely related strains than previously suspected. A DNA probe for a 721 bp region of the NiR structural gene was obtained by PCR amplification of $P$. stutzeri (ATCC 14405) DNA and used to screen denitrifying strains and isolates. The probe hybridized with a greater variety of strains than did the antiserum, implying that the DNA probe may be a more broadly useful and functional probe in environmental samples, whilst the NiR antiserum is nearly strain- or, at most, species-specific. Limits for detection of the enzyme and gene in seawater were estimated and NiR DNA was detected in DNA extracted from natural seawater. The hybridization data imply that in the order of 1-10 in 1000 cells in natural seawater possess homology with the NiR gene probe.
\end{abstract}

\section{Introduction}

Denitrification as a form of anaerobic respiration by facultatively anaerobic heterotrophic bacteria leads to net loss of fixed nitrogen from the ecosystem. Nitrite reductase $(\mathrm{NiR})$, the second enzyme in the sequential reduction of nitrate to dinitrogen, has been investigated as a key enzyme in the inducible denitrification pathway. Antisera for NiR have been used to study its induction in culture experiments (Korner \& Zumft, 1989) and to screen isolates for possession of the enzyme (Korner et al., 1987; Coyne et al., 1989). Korner \& Zumft (1989) reported that an antiserum produced against $\mathrm{NiR}$ purified from $P$. stutzeri (ATCC 14405) was essentially strain-specific for $P$. stutzeri (ATCC 14405), crossreacting with one other strain of $P$. stutzeri but not with all $P$. stutzeri strains tested. Coyne et al. (1989) produced antisera for the haem $\mathrm{cd}_{1} \mathrm{NiRs}$ purified from a different strain of P. stutzeri (JM300), and from P. aeruginosa. The $P$. aeruginosa antiserum reacted with denitrifiers in other genera, as well as with other Pseudomonas species, including $P$. stutzeri and $P$. fluorescens, while the $P$. stutzeri JM300 antiserum apparently did not react with

*Author for correspondence. Tel. (408) 459 3171; fax (408) 459 4882; internet bbw $@$ cats.ucsc.edu.

Abbreviation: NiR, nitrite reductase.
$P$. aeruginosa. The two antisera (results combined) identified $64 \%$ and $92 \%$ of denitrifying isolates in two collections as possessing the $\mathrm{cd}_{1}$ haem NiR.

Little is known about the taxonomic identity and diversity of denitrifying bacteria in the marine environment. Gamble et al. (1977) reported that Pseudomonas was the dominant denitrifying genus isolated from a wide variety of soil samples from diverse environments. The results of Coyne et al. (1989) and Gamble et al. (1977) together implied that denitrifying pseudomonads containing the $\mathrm{cd}_{1}$ haem-type NiR might also be important in marine systems. We chose Pseudomonas stutzeri ATCC 14405 (formerly $P$. perfectomarina) as a type-strain for our work, based on the fact that it was originally isolated from the marine environment (isolated from seawater and marine muds off the coast of California by Zobell \& Upham, 1944) and because of the existing data base for this organism. We report the characterization of a new antiserum, produced against NiR from P. stutzeri (ATCC 14405), and our initial evaluation of the potential of such a probe for investigation of denitrification in the marine environment.

The biochemistry of NiR has suggested that the enzyme was highly conserved among denitrifiers (Bryan, 1981). This conclusion is not entirely supported by the minimal degree of cross-reactivity of NiR antisera 
(Korner et al., 1987; Coyne et al., 1989). Greater immunological cross-reactivity among the proteins would have been predicted from the similarity subsequently observed among NiR gene sequences $(P$. stutzeri ATCC 14405, Jungst et al., 1991; P. aeruginosa, Sylvestrini et al., 1989; P. stutzeri JM300, Smith \& Tiedje, 1992). Smith \& Tiedje (1992) also screened a series of denitrifying strains for hybridization with probes developed from the NiR sequence and reported that such probes correctly identified most $\mathrm{cd}_{1}$ haem-type denitrifiers. Using these published sequences, we produced a probe for a $721 \mathrm{bp}$ region of the NiR structural gene from P. stutzeri (ATCC 14405) and used it to screen denitrifiers from culture collections and unidentified marine isolates. Different degrees of specificity were obtained for the DNA probe and the antibody probe developed from the same type-strain. The two probes promise different kinds of information when applied as probes for environmental studies.

\section{Methods}

Strains and isolates. Specific strain designations are essential for interpretation of our results, so we refer to strains by name and number throughout. Pseudomonas stutzeri (ATCC 14405) was obtained from the American Type Culture Collection and used as our primary strain. It was maintained in CP medium (Carlucci \& Pramer, 1957) containing 1-10 g peptone $\mathrm{l}^{-1}$ of aged natural seawater. Several other strains were purchased from ATCC or obtained from colleagues (Table 1) and

Table 1. Tests using immunofluorescence (IIF, whole cell assay), nitrite reductase antiserum and nitrite reductase 721 bp gene probe

Results are expressed on the subjective scale from - (no reaction) to ++++ (maximum reaction). For the NiR antisera tests (NiR ab), equal amounts of total protein were loaded in each lane and results are reported from Western blots of partially purified enzyme preparations. For the NiR gene probe (NiR DNA), equal amounts of total genomic DNA were loaded into slots for probing. ND, Not determined.

\begin{tabular}{lccc}
\hline \hline Denitrifying strain & IIF reaction & NiR ab & NiR DNA \\
\hline Pseudomonas stutzeri & ++++ & ++++ & ++++ \\
ATCC 14405 & & & \\
MK202 & +++ & +++ & ++++ \\
P. stutzeri ATCC 11607 & + & ++ & ++++ \\
P. stutzeri ATCC 17588 & ++ & $+/-$ & +++ \\
P. stutzeri JM300 & ++ & + & ++++ \\
P. aurefaciens ATCC 13985 & - & - & - \\
P. denitrificans ATCC 13867 & - & - & ++ \\
P. atlantica & - & - & - \\
P. putida & - & - & ND \\
P. fuorescens ATCC 33512 & ++ & - & + \\
P. aeruginosa & - & - & +++ \\
Alcaligenes faecalis & - & - & + \\
ATCC 8750 & - & - & - \\
Paracoccus denitrificans & - & - & - \\
ATCC 19367 & - & & \\
Thiosphaera pantotropha & - & & \\
\hline
\end{tabular}

maintained in LB medium ( $5 \mathrm{~g}$ yeast extract, $10 \mathrm{~g}$ tryptone, $10 \mathrm{~g} \mathrm{NaCl}$ at $\mathrm{pH} 7$ in $1 \mathrm{I}$ distilled water) or $\mathrm{CP}$ medium as appropriate. All strains were stored with $15 \%(\mathrm{v} / \mathrm{v})$ glycerol at $-70^{\circ} \mathrm{C}$.

For isolations, we used two standard enrichment media containing nitrate plus either a complex carbon source [peptone; CP medium amended with $1 \mathrm{mM}-\mathrm{KNO}_{3}$ ) or succinate (per litre of aged seawater: $10 \mathrm{~g} \mathrm{KNO}_{3}, 0.05 \mathrm{~g} \mathrm{~K}_{2} \mathrm{HPO}_{4}, 0.2 \mathrm{~g} \mathrm{MgSO}_{4} .7 \mathrm{H}_{2} \mathrm{O}, 0.1 \mathrm{~g} \mathrm{CaCl}_{2} .2 \mathrm{H}_{2} \mathrm{O}$, $4 \mathrm{~g} \mathrm{Na}$ succinate, $1 \mathrm{ml}$ trace metals solution (Biebl \& Pfennig, 1978)]. Samples of seawater $(1 \mathrm{ml})$ or sediment (approximately $1 \mathrm{~g}$ ) were inoculated into $10 \mathrm{ml}$ enrichment medium in screw cap tubes containing inverted Durham tubes. Isolates were streaked to purity on CP plates incubated in a nitrogen atmosphere. Ability of isolates to denitrify was ascertained by sequential growth in liquid $\mathrm{CP}$ medium in oxygen, then nitrate, then nitrite as electron acceptors. Ability to grow on $\mathrm{NO}_{2}^{-}$ $(0.01-0-25 \% \mathrm{w} / \mathrm{v})$ and detection of $\mathrm{N}_{2} \mathrm{O}$ (by ECD gas chromatography; see below) in the headspace of the culture tube were taken as evidence of ability to denitrify completely and therefore that the strain possessed some form of nitrite reductase.

Enrichments were maintained as close as possible to the original ambient temperature until pure isolates were obtained. The isolates were then stored in glycerol at $-70^{\circ} \mathrm{C}$. Subsequent growth of isolates for protein purification or screening took place at approximately $25^{\circ} \mathrm{C}$.

Purification of nitrite reductase from $P$. stutzeri. $P$. stutzeri (ATCC 14405 ) was grown in 31 batch cultures in sealed 41 bottles (CP medium containing $10 \mathrm{~g}$ peptone $\mathrm{I}^{-1}$ and $0.25 \% \mathrm{NO}_{2}^{-}$) inoculated from a dense exponential-phase culture growing with nitrite as the terminal electron acceptor. Cells were harvested by centrifugation $(4000 \mathrm{~g})$ at $4{ }^{\circ} \mathrm{C}$ and resuspended in column buffer ( $25 \mathrm{~mm}$-Tris, $\mathrm{pH} 8.2$, at $12^{\circ} \mathrm{C}$, containing $10 \%$ glycerol, $1 \mathrm{~mm}$-EDTA, $1 \mathrm{~mm}$-dithiothreitol, $0.3 \mathrm{~mm}-\mathrm{PMSF}$, $0.02 \%$ sodium azide). Cells resuspended in this buffer were frozen or disrupted on ice immediately using a Bead-Beater (Biospec Products). All subsequent treatments were carried out in a constant temperature room at $12^{\circ} \mathrm{C}$.

Homogenate was dialysed against column buffer and then centrifuged for $15 \mathrm{~min}$ at $12000 \mathrm{~g}$. The supernatant was loaded onto a column of Whatman DE53 cellulose; the green-brown bound proteins eluted with $100 \mathrm{~mm}-\mathrm{NaCl}$ in column buffer. Fractions were assayed for absorption at $410 \mathrm{~nm}, 280 \mathrm{~nm}$ and $260 \mathrm{~nm}$ to estimate protein concentration $\left(1.55 A_{280}-0.76 A_{260}\right)$ and to identify the maximum cytochrome concentration ( $410 \mathrm{~nm}$ absorption peak).

Fractions containing the $410 \mathrm{~nm}$ maximum were pooled and loaded onto a large $(90 \mathrm{ml})$ column of Sephacryl S200 (Pharmacia) and eluted with column buffer. Fractions were again assayed for absorption at the three wavelengths and the green cytochrome peak was dialysed against $40 \%$ glycerol in column buffer and stored at $-20^{\circ} \mathrm{C}$. Protein concentration at this point was approximately $1 \mathrm{mg} \mathrm{m}^{-1}$.

The partially purified NiR preparation was then electrophoresed using a large format Hoefer polyacrylamide gel with a preparative comb (see below). The bands containing NiR had been localized previously using the in situ gel assay (see below) and could be identified by their faint brown colour or could be visualized by brief soaking in $0.3 \mathrm{M}^{-\mathrm{CuCl}_{2}}$ solution. These bands were excised from several gels, pooled, minced, covered with $5 \times$ running buffer and electroeluted. The eluate was concentrated using Ultrafree spin concentrators (Millipore, $30000 M_{\mathrm{r}}$ cut-off). The concentrate was washed in phosphate-buffered saline (PBS; $10 \mathrm{~mm}$-phosphate, $150 \mathrm{mM}-\mathrm{NaCl}, \mathrm{pH} \mathrm{7.4)} \mathrm{and} \mathrm{stored} \mathrm{with}$ $40 \%$ glycerol at $-20{ }^{\circ} \mathrm{C}$.

Approximately $1 \mathrm{mg}$ of $\mathrm{NiR}$ protein was collected in this way and used to immunize rabbits by the following schedule: day 1, perilymph nodal injection using Freund's complete adjuvant; day 21, intramuscular booster injection using Freund's incomplete adjuvant; day 33, bleed; day 43, booster injection; day 54, bleed (Berkeley Antibody Company). The antisera were initially titred using a dot-blot assay (see below) against the immunizing antigen. Before use in the specificity 
testing described below, the antiserum was adsorbed against a lysate of aerobically grown P. stutzeri (ATCC 14405) cells.

PAGE. Non-denaturing PAGE was done with a $6.5 \%$ (w/v) resolving gel and a $3 \%$ stacking gel. Small native gels were used to characterize fractions during purification of the enzyme and to prepare samples for the gel activity assay (see below). Large native gels were used to collect large quantities of purified protein for immunization. Native gels were then used in the gel activity assay or stained using Coomassie blue or silver-stained (Ansorge, 1985).

For SDS-polyacrylamide denaturing gels, the resolving gel was $10 \%$ $(\mathrm{w} / \mathrm{v})$ and the stacking gel was $4 \%$ acrylamide, and both contained $0.1 \%$ SDS. Denaturing gels were prepared for Western blotting (see below) or stained as above. The molecular mass of unknown samples was estimated by comparison with molecular mass standards.

Preparation of crude lysates. Cells were grown under anaerobic conditions in the presence of $0.01-0.25 \% \mathrm{NO}_{2}^{-}$(depending on the strain's tolerance for $\mathrm{NO}_{2}^{-}$). Although cells grown on nitrate also express $\mathrm{NiR}$, we routinely grew cells on nitrite to be certain that NiR was present and to obtain $\mathrm{NiR}$ as a high enough fraction of total cell protein to obtain strong bands in the gel assay (see below). Cells $(50 \mathrm{ml}$ late exponential phase culture) were harvested by centrifugation, resuspended in $0.5 \mathrm{ml}$ lysis buffer $(0.1 \%$ Triton $\mathrm{X}-100,0.3 \mathrm{mg}$ lysozyme $\mathrm{ml}^{-1}$ in column buffer at $50 \mathrm{~mm}$-Tris) and incubated for $1 \mathrm{~h}$ on ice. $\mathrm{MgCl}_{2}(0.01 \mathrm{M}), 0.1 \mathrm{mg}$ DNAase $\mathrm{ml}^{-1}$ and $0.1 \mathrm{mg} \mathrm{RNAase} \mathrm{ml}^{-1}$ were added and incubated for $1 \mathrm{~h}$. Crude lysates were frozen immediately, or diluted in PBS and stored in $40 \%$ glycerol at $-20^{\circ} \mathrm{C}$.

For recovery of NiR from cells in natural seawater, $1-41$ of seawater were filtered onto $0.2 \mu \mathrm{m}$ pore size $47 \mathrm{~mm}$ diameter Nuclepore filters and frozen in $0.5 \mathrm{ml}$ lysis buffer. Upon thawing, protein was precipitated from the lysate by the addition of an equal volume of acetone. Precipitates were dried and redissolved in SDS sample buffer for electrophoresis (see above).

Activity assays for NiR. Fractions from column chromatographic separations (above) were assayed for nitrite reductase activity (by nitrite disappearance) in an anaerobic liquid assay similar to that described by Zumft et al. (1987). The active enzyme was localized in non-denaturing polyacrylamide gels using an anaerobic gel assay (Zumft et al., 1987) performed in a nitrogen-flushed glove bag.

Immunoblotting. Western blots were prepared from SDS-PAGE gels by standard protocols (Towbin et al., 1979) using Immobilon $P$ (Millipore) membranes. The antiserum concentration varied among runs but the standard protocol used a dilution of 3000 -fold. The secondary antibody was goat anti-rabbit IgG linked to alkaline phosphatase and was used at a 1000 -fold dilution. Blots were blocked using non-fat dry milk and developed with nitro-blue tetrazolium and 5-bromo-4-chloro-3-indolyl-phosphate substrate. Dot-blot assays were performed by dropping samples of $S \mu l$ or less onto Immobilon $P$ mem? anes, which were then incubated and developed as for Western blots.

Immunofuorescence. An antiserum (prepared using whole cells as an immunogen) which reacts specifically with P. stutzeri (ATCC 14405) and less intensely with other strains of $P$. stutzeri in immunofluorescence reactions has been described previously (Ward \& Cockeroft, 1993). We screened isolates and strains for immunofluorescence cross reactions using the method of Ward \& Carlucci (1985) followed by DAPI staining (Porter \& Feig, 1980), in order to compare the specificity of the cell surface (immunofluorescence) and NiR (Western blots) antisera.

NiR DNA probe. Using the published sequence for the structural gene of nitrite reductase from $P$. stutzeri (ATCC 14405) (Jungst et al., 1991), we designed PCR primers (5' CGCCAGAGTTCTCCCTGCAG and 3' CAGCTGTGGTTCTGGCCGTT) to amplify a 721 bp region of the NiR gene. This fragment included a central region of the gene that was reported to be highly homologous with $\mathrm{NiR}$ from $P$. aeruginosa (Sylvestrini et al., 1989) and P. stutzeri JM300 (Smith \& Tiedje, 1992). The fragment represents the section between 628 and $1349 \mathrm{bp}$ from the $\mathrm{N}$ terminus of the gene sequence in P. stutzeri (ATCC 14405) (Jungst et al., 199!). We used Taq polymerase (Promega) with the manufacturer's buffer at a $\mathrm{Mg}^{2+}$ concentration of $1.5 \mathrm{~mm}$ Amplification $\left(35\right.$ cycles of $1 \mathrm{~min}$ at $94^{\circ} \mathrm{C}, 1 \mathrm{~min}$ at $55^{\circ} \mathrm{C}, 2 \mathrm{~min}$ at $72^{\circ} \mathrm{C}$ ) resulted in production of one fragment of approximately $700 \mathrm{bp}$. The amplified product was purified (Geneclean, Bio 101) and labelled by random priming with digoxygenin-labelled nucleotides according to the manufacturer's protocol (Genius kit, Boehringer Mannheim).

Genomic DNA was isolated from bacterial cultures following standard protocols (Ausubel et al., 1987) and its concentration estimated by absorption at $260 \mathrm{~nm}$. Genomic DNA was digested with restriction enzymes (Boehringer Mannheim) according to the protocols recommended by the manufacturers, electrophoresed and transfcrred to Nytran (Schleicher \& Schuell), or Immobilon $\mathbf{P}$ (Millipore) membranes by Southern blotting (Southern, 1975). Blots were hybridized to the labelled $\mathrm{NiR} 721 \mathrm{bp}$ fragment in $5 \mathrm{ml}$ hybridization solution $[0-3 \%$ SDS, $5 \times \mathrm{SSC}(20 \times \mathrm{SSC}=175 \mathrm{~g} \mathrm{NaCl}$ and $88 \mathrm{~g} \mathrm{Na}$ citrate $\left.1^{-1}\right), 3 \%(\mathrm{w} / \mathrm{v})$ powdered milk, $0.5 \mathrm{mg}$ sheared salmon sperm DNA $\mathrm{ml}^{-1}$ ] overnight at $65^{\circ} \mathrm{C}$. Blots were washed and developed according to the manufacturer's protocol (Genius kit, Boehringer Mannheim) using a colorimetric substrate for alkaline phosphatase. Initial screening for homology between the $\mathrm{NiR}$ probe and unknown isolates was by slot blotting, using $1 \mu \mathrm{g}$ DNA per slot, and hybridizing and developing as for Southern blots.

Samples for extraction of DNA from seawater were collected using 30 I Niskin samplers from the Santa Barbara Channel (off the coast of California) in approximately $900 \mathrm{~m}$ of water. Samples (1 l) were filtered onto $0.2 \mu \mathrm{m}$ pore size, $47 \mathrm{~mm}$ diameter polysulphone membrane filters (Gelman). Filters were placed in cryovials and frozen in $0.5 \mathrm{ml}$ EDTA $(0.5 \mathrm{M})$. Cells were lysed by the addition of $100 \mu 10.5 \mathrm{M}$-EDTA containing $3 \mathrm{mg}$ lysozyme, followed by $20 \mu \mathrm{l} 10 \%$ (w/v) SDS and incubation at room temperature for 10-30 min. Pronase or proteinase $\mathrm{K}\left(35 \mu \mathrm{l}\right.$ at $10 \mathrm{mg} \mathrm{ml}^{-1}$ in TE) was added and incubated for $1 \mathrm{~h}$ at $50{ }^{\circ} \mathrm{C}$. The preparation (still containing the undissolved filter) was extracted with an equal volume of phenol followed by chloroform/ isoamyl alcohol $(24: 1, v / v)$, then precipitated with propanol. The final DNA preparations were frozen in TE and an aliquot of each sample (representing the DNA extracted from $500 \mathrm{ml}$ seawater) was hybridized in slot blots as above.

Ancillary chemical measurements and sources of materials. Chemicals were obtained from Fisher or Sigma with exceptions as noted. Nitrite was assayed by the spectrophotometric method of Bendschneider \& Robinson (1952) using a Hitachi double beam spectrophotometer. The same spectrophotometer was programmed to read three absorbances $(260 \mathrm{~nm}, 280 \mathrm{~nm}, 410 \mathrm{~nm})$ for characterization of protein and cytochrome content of column chromatography fractions during the NiR purification procedure. Nitrous oxide was detected using a Shimadzu Mini-2 gas chromatograph equipped with an electron capture detector and a $2 \mathrm{~m}$ Poropak $\mathrm{Q}$ column run at an injection temperature of $300^{\circ} \mathrm{C}$ and a column temperature of $45^{\circ} \mathrm{C}$. Gas standards were obtained from Scott Specialty Gases. Protein concentrations were assayed by the method of Bradford (1976).

\section{Results}

Purification of NiR

After the purification procedure described above, SDSPAGE of the concentrated electroeluate showed one major band with an approximate molecular mass of 
(a)

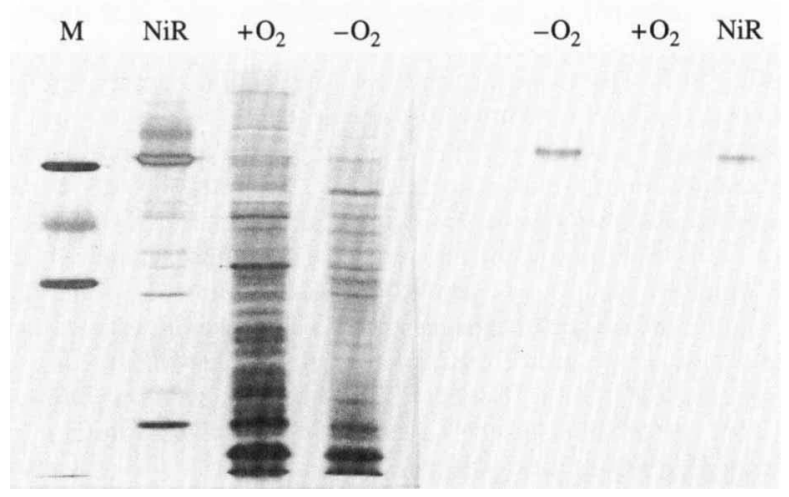

Fig. 1. (a) Silver-stained SDS-PAGE gel and $(b)$ Western immunoblot of purified protein preparations separated on SDS-PAGE gel probed with anti-NiR antiserum from P. stutzeri (ATCC 14405). Lanes: M, molecular mass standards $(67,45,29 \mathrm{kDa})$; NiR, purified NiR preparation from $P$. stutzeri (ATCC 14405); $+\mathrm{O}_{2}$, total protein from lysate of aerobically grown $P$. stutzeri (ATCC 14405); $-\mathrm{O}_{2}$, total protein from lysate of anaerobically grown P. stutzeri (ATCC 14405).

$66 \mathrm{kDa}$. The procedure resulted in a 22 -fold purification from approximately $10 \mathrm{~g}$ cells, for a yield of $0.033 \%$. The final preparation had a specific activity of $1-2 \mathrm{nmol}$ $\mathrm{NO}_{2}^{-} \mathrm{s}^{-1} \mathrm{mg}^{-1}$.

Enzyme activity was maintained throughout the purification procedure. Activity was inhibited by oxygen, but exposure of the protein to oxygen during the normal manipulation of PAGE did not appear to inhibit its subsequent activity under anaerobic assay conditions. The gel assay identified one major active band in nondenaturing gels, which could be resolved in lightly loaded gels into two bands very close together. Because both bands were active, we made antisera to each of them separately, suspecting that they represented slightly modified forms of the same enzyme.

\section{Characterization of the NiR antisera}

The antisera resulting from the separate immunizations of the two active bands could not be distinguished in terms of sensitivity or specificity and so will be treated as one antiserum. We ascertained that the antiserum was specific for nitrite reductase in the homologous system by (1) demonstrating that it reacted with the putative NiR band in SDS-PAGE gels prepared from anaerobically grown cells but did not react with proteins in SDSPAGE gels prepared from aerobically grown cells (Fig. 1); (2) demonstrating that the presence of the antiserum in the liquid assay inhibited enzyme activity (Table 2); and (3) demonstrating that the band identified in Western blots was the same band shown to be active by the gel assay in duplicate non-denaturing gels (Fig. 2).

To characterize the species specificity of the NiR antiserum, we tested strains known to contain the $\mathrm{cd}_{1}$

Table 2. Inhibition of NiR enzyme activity by anti-NiR antibody from P. stutzeri (ATCC 14405)

\begin{tabular}{lcccc}
\hline Source of NiR enzyme & $\begin{array}{c}\text { Antibody: } \\
\text { antigen }\end{array}$ & $\begin{array}{c}\text { Percentage } \\
\text { activity* }\end{array}$ & SD & $n$ \\
\hline P. stutzeri ATCC 14405 & 2 & 21 & 7 & 5 \\
P. stutzeri JM300 & 5 & 101 & 4.6 & 5 \\
P. stutzeri ATCC 11607 & 2 & 50 & 22 & 4 \\
$P$. stutzeri ATCC 17588 & 2 & 82 & 22 & 4 \\
\hline \hline
\end{tabular}

SD, Standard deviation; $n$ no. of determinations.

*A percentage of the reaction rate observed in the uninhibited $P$. stutzeri ATCC 14405 control (defined as $100 \%$ ).

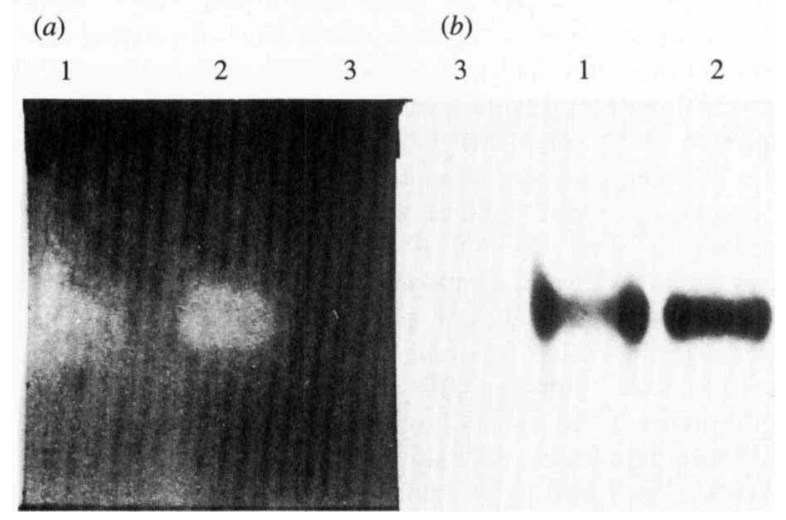

Fig. 2. Identification of active NiR band in gel assay and Western blot. (a) Nitrite reductase activity stain in native gel of $P$. stutzeri (ATCC 14405) NiR. (b) Western blot of native gel probed with NiR antiserum. Lanes: 1 , anaerobic lysate; 2 , purified $\mathrm{NiR}$ preparation from anaerobic cells; 3 , aerobic lysate.

haem-type of NiR found in P. stutzeri, strains known to contain the Cu-type $\mathrm{NiR}$, and isolates (uncharacterized as to NiR type) obtained from marine water column and sediment environments using Western blots of lysates of nitrite-grown cells. Among known denitrifying strains (Table 1), the antiserum reacted only with lysates prepared from $P$. stutzeri strains. Cross-reacting proteins appeared to be of very similar subunit size in Western blots prepared from denaturing gels (Fig. 3).

With slight modifications as required, the protocol by which $\mathrm{NiR}$ was purified from $P$. stutzeri (ATCC 14405) was used to obtain purified protein from other $P$. stutzeri strains. Localization of NiR activity in non-denaturing PAGE gels showed that $P$. stutzeri JM 300 has an enzyme of apparently different composition from the one purified from P. stutzeri (ATCC 14405) in this study (Fig. 4). Whilst the P. stutzeri (ATCC 14405) antiserum reacted with JM300 and 11607 , it did not react with $P$. aeruginosa (Fig. 3). In Western blots from denaturing gels, the reactive bands from heterologous strains appear to have a subunit size very similar to that of $P$. stutzeri (ATCC 14405 ). However, these proteins run differently in native gels, even when protein concentration, buffer concen- 


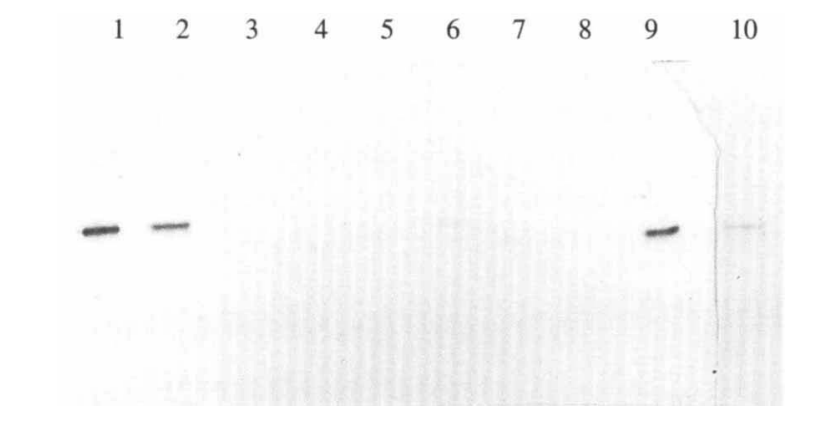

Fig. 3. Western immunoblot from SDS-PAGE of NiR antibody reactions with $\mathrm{NiR}$ in lysates of several known denitrifying strains. Positive reactions are detected in lanes 1, 2, 6, 9, 10. Lane I, control: original antigen preparation, purified NiR from $P$. stutzeri (ATCC 14405); lanes 2-9, lysates: 2, P. stutzeri (ATCC 14405); 3, P. fuorescens; 4 , P. denitrificans; 5 , Paracoccus denitrificans; $6, P$. stutzeri (ATCC 11607); 7, P. stutzeri (ATCC 17588); 8, Escherichia coli; 9, MK202 ( $P$. stutzeri ATCC 14405 mutant); 10, P. stulzeri JM300.

tration and $\mathrm{pH}$ were standardized for each lane (Fig. 4). We conclude that a common subunit is responsible for the observed cross reactions, even if the native protein is of different composition or configuration. Antibody inhibition experiments in the liquid activity assay also indicate strain specificity of the NiR antiserum (Table 2).

\section{NiR DNA probe}

MK202 is a transposon mutant of $P$. stutzeri (ATCC 14405) (Zumft, et al., 1988) which was a gift from W. Zumft, Universität Karlsruhe, Germany. The mutation in the NiR operon caused by insertion of Tn5 allowed localization of the NiR sequences in genomic Southern blots by probing with labelled $\mathrm{Tn} 5$. The origin of the $721 \mathrm{bp}$ fragment was verified as a fragment of the $\mathrm{NiR}$ gene by the fact that the $721 \mathrm{bp}$ probe and the $\operatorname{Tn} 5$ probe both hybridized to the same bands in Southern blots of genomic digests of MK202 (not shown). The $721 \mathrm{bp}$ NiR probe was found to hybridize with several known denitrifier strains (Table 1), including the $P$. stutzeri strains which reacted with the $\mathrm{NiR}$ antiserum and several others. It did not hybridize with the strains known to contain the Cu-type $\mathrm{NiR}$ ( $P$. aureofaciens, Thiosphaera pantotropha).

\section{Screening of denitrifying isolates}

The SCB series of denitrifying isolates was obtained from bottom water at $900 \mathrm{~m}$ in a marine basin which is depleted in oxygen and shows slight nitrate depletion just above the sediment surface (Jahnke, 1990). The TBD series of isolates were obtained from intertidal microbial mat sediments on the eastern shore of Tomales Bay, CA. The two series of isolates were screened with the set of probes described here: the species-specific (whole cell)

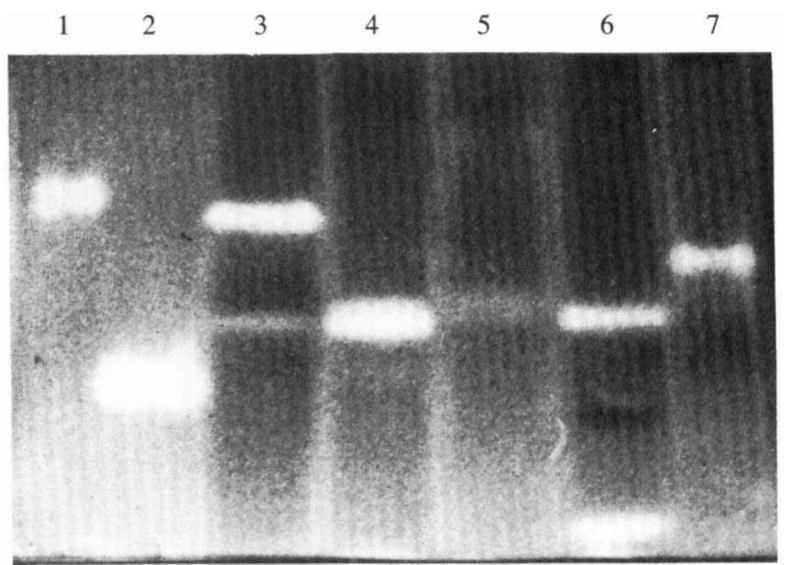

Fig. 4. Identification of active NiR bands in native gel assay of crude extracts from various denitrifying strains. Lanes: $1, P$. stutzeri (ATCC 14405); 2, P. stutzeri JM300;3, P. stutzeri (ATCC 17588); 4, P. stutzeri (ATCC 11607); 5, SCB-6; 6, P. aeruginosa; 7, Alcaligenes faecalis.

Table 3. Tests using immunofluorescence (IIF, whole cell assay), nitrite reductase antiserum and nitrite reductase 721 bp gene probe reactions for unidentified denitrifying isolates

\begin{tabular}{llll}
\hline Strain & IIF reaction & NiR ab & NiR DNA
\end{tabular}

(a) Isolates from Southern California Bight $\left(900 \mathrm{~m}^{*}\right.$

SCB-4

SCB-6

SCB-8

SCB-14

SCB-16

SCB-18

SCB-20

-
-
-
$-1+$
-
-

-
-
-
-

(b) Isolates from Tomales Bay sediments $\dagger$

TBD-8

TBD-9

TBD-21

TBD-22

$\begin{array}{rrr}-- & + & - \\ 19 & 0 & 5 \\ 21 & 0 & 13 \\ 21 & 0 & 0\end{array}$

$\begin{array}{ll}- & + \\ - & + \\ - & \mathrm{ND} \\ - & - \\ - & + \\ - & - \\ - & +\end{array}$

\footnotetext{
ND, Not determined.

* No attempt was made to normalize to total protein or NiR protein content in Western blots of crude lysates of the environmental isolates. Therefore, the antibody reaction (NiR ab) results are reported as - (no reaction) or + (positive reaction). The DNA samples (NiR DNA), however, were normalized to DNA concentration but are reported as - or + for consistency with the antibody results. Results are reported only for isolates which were subjected to all three probe tests.

+ Twenty or more isolates were obtained from each 1-2 mm layer of microbial mat. The number of isolates from each layer which reacted $(+)$ or not $(-)$ is shown.
}

immunofluorescent assay, the NiR antiserum and the 721 bp NiR DNA probe. None of the isolates reacted with the strain-specific immunofluorescent assay (Table 3). P. stutzeri (ATCC 14405) has been identified and enumerated in waters and sediments from these environments using this antiserum (Ward and Cockcroft, 1993), so although this strain is present, it is not the dominant strain isolated by our enrichment methods. 
(a)

(b)

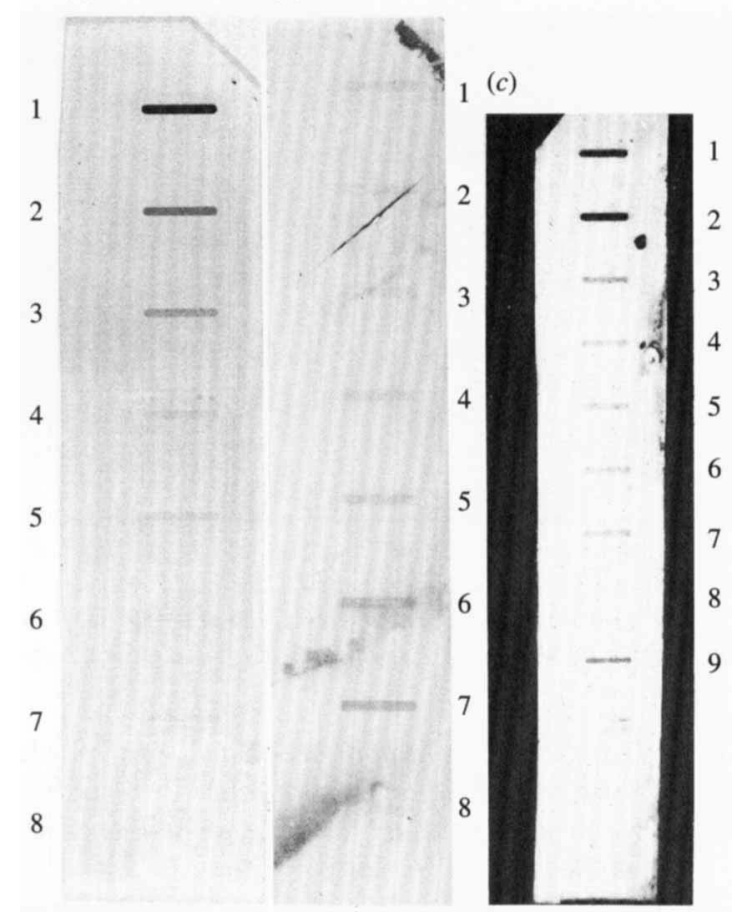

Fig. 5. Slot blots of DNA. (a) Determination of detection limit for NiR DNA probe using P. stutzeri (ATCC 14405) genomic DNA. Slots: 1, $1056 \mathrm{ng} ; 2,528 \mathrm{ng} ; 3,264 \mathrm{ng} ; 4,26 \cdot 4 \mathrm{ng} ; 5,2.64 \mathrm{ng} ; 6$, no DNA; 7, $2 \mu \mathrm{g}$ salmon sperm DNA; 8, no DNA. (b) DNA extracts from $P$. stutzeri (ATCC 14405) preserved and prepared in various ways. Source of DNA in slots: 1 and 2,1 ml exponential-phase culture preserved in formalin; 3 and $4,1 \mathrm{ml}$ exponential-phase culture preserved in formalin and diluted in $20 \mathrm{ml}$ seawater; $5,200 \mathrm{ml}$ unamended surface seawater, Monterey Bay collected on Nuclepore filter; $6,500 \mathrm{ml}$ unamended surface seawater, Monterey Bay collected on supor filter; 7, $44 \mathrm{ng} P$. stutzeri (ATCC 14405) genomic DNA; 8, $2 \mu$ g salmon sperm DNA. (c) DNA extracts from different depths of Santa Barbara Channel seawater. Each slot represents DNA from $500 \mathrm{ml}$ seawater. Extracted DNA in $50 \mu \mathrm{l}$ TE was slotted and hybridized against the NiR $721 \mathrm{bp}$ probe as described. Slots: $1,0 \mathrm{~m} ; 2,40 \mathrm{~m} ; 3,80 \mathrm{~m} ; 4,120 \mathrm{~m} ; 5,160 \mathrm{~m}$; $6,200 \mathrm{~m} ; 7,250 \mathrm{~m} ; 8,2 \mu \mathrm{g}$ salmon sperm DNA; $9,44 \mathrm{ng} P$. stutzeri (ATCC 14405) genomic DNA.

None of the isolates from the water column reacted with the NiR antiserum (Table $3 a$ ). However, several of the isolates from Tomales Bay sediments did cross react with the NiR antiserum (Table $3 b$ ), and had a subunit size apparently identical to that of $P$. stutzeri (ATCC 14405). Four of the SCB isolates and several of the TBD isolates hybridized with the NiR probe (Table 3 ). These strains were isolated from the subsurface layer $(2-4 \mathrm{~mm})$ of a cyanobacteria-dominated mat that had previously been shown to exhibit high denitrification rates in the upper $5 \mathrm{~mm}$ (Joye \& Paerl, 1993). We have not characterized the isolates beyond shape, ability to denitrify, and in terms of the probes used here. Thus, we do not know how many different organisms are represented, but shape alone suggests that two or three major types were obtained from each layer. Although none of these strains reacted with the cell surface antiserum, we conclude that they are probably $P$. stutzeri strains or close relatives, since the NiR antiserum is also very specific. Four of the SCB isolates and several of the TBD isolates hybridized with the NiR probe.

\section{Detection of NiR enzyme and NiR DNA in seawater samples}

The sensitivity of the NiR antiserum was tested on dilutions of NiR in Western blots. The limit of detection for the purified protein was an amount of enzyme approximately equivalent to $2 \times 10^{4}$ denitrifying cells. The sensitivity of the NiR antiserum in complex samples was tested by diluting P. stutzeri (ATCC 14405) into natural seawater, filtering the sample onto a $0.2 \mu \mathrm{m}$ filter, and preparing a crude lysate from the material on the filter (see Methods). Western blots labelled with the NiR antiserum detected NiR in samples containing $2 \times 10^{5}$ cells. The number of $P$. stutzeri cells present in the dilutions was determined by indirect immunofluorescence (IIF) enumeration of preserved aliquots (Ward \& Cockcroft, 1993).

NiR protein was not unequivocally detected in Western blots of the seawater samples we analysed. We have not yet had the opportunity to sample strongly denitrifying conditions. Because the presence of the enzyme is dependent upon conditions which induce its expression, a definitive test of the assay in natural samples awaits this opportunity.

Sensitivity of the $721 \mathrm{bp}$ probe hybridization assay was estimated by hybridization of slot blots containing a range of $P$. stutzeri (ATCC 14405) DNA concentrations. In several different dilution series, the smallest amount of DNA yielding a positive result was $0.44 \mathrm{ng}$. In the blot shown in Fig. 5(a), hybridization was detected at the lowest amount of DNA tested, $2.6 \mathrm{ng}$ (slot 5). Therefore, the detection limit estimated from this blot is less than $2.6 \mathrm{ng}$ total DNA. The probe reacts only with a $721 \mathrm{bp}$ region (assuming no messenger RNA was present at the time of collection). If the $P$. stutzeri genome is approximately $5.9 \times 10^{6}$ bp (estimated by assuming it is the same size as that of $P$. aeruginosa; Romling et al., 1989) and there is only one copy of the gene per genome, the total DNA of $2.6 \mathrm{ng}$ corresponds to less than $0.3 \mathrm{pg}$ of NiR DNA. The suggested limit of detection for the Genius system with colorimetric detection is $0.1 \mathrm{pg}$. If we take the actual detection limit as $0.3 \mathrm{pg}$, this corresponds to $4.26 \times 10^{5}$ copies of the fragment. Again assuming only one copy per genome, this corresponds to the presence of $4.26 \times 10^{5}$ cells containing NiR DNA.

We tested the ability of the NiR probe to hybridize with DNA from P. stutzeri (ATCC 14405) that had been preserved in $2 \%(\mathrm{v} / \mathrm{v})$ formalin and with DNA extracted 
from unamended seawater. All treatments yielded positive hybridization results compared with the negative control (hybridization between the $\mathrm{NiR}$ probe and salmon sperm DNA) (Fig. 5b). NiR DNA was also detected in samples between 0 and $250 \mathrm{~m}$ in the Santa Barbara Channel (Fig. $5 c$ ). The strength of the reaction in the seawater samples corresponds roughly to the amount of DNA extracted from the sample, and thus cannot be interpreted in terms of relative abundance of $\mathrm{NiR}$ bearing cells within the total cell population at each depth. Quantification of the hybridization reaction requires a larger amount of DNA, and is under development.

\section{Discussion}

\section{Relative specificity of probes}

The specificity of the immunofluorescence assay for $P$. stutzeri (ATCC 14405) described previously (Ward \& Cockcroft, 1993) is the level of specificity often obtained with cell surface assays. The antiserum was prepared using whole cells as the immunogen, and five immunoprecipitin lines are observed when analysed by Ouchterlony double immunodiffusion using homogenates of whole cells (not shown). The cell surface reaction visualized by immunofluorescence is probably due to reaction with one or a few epitopes on the outer surface of the Gram-negative cell membrane, which can be extremely strain-specific. Thus species or strain specific immunofluorescence assays have been reported for enumeration of several other bacteria in marine and other natural systems (e.g. Schmidt et al., 1968; Dahle \& Laake, 1982; Campbell et al., 1983; Ward \& Carlucci, 1985).

This degree of strain specificity was not expected in response to immunization with purified nitrite reductase. The antiserum was raised against native protein, but reacts equally well with both native and denatured protein in the homologous system. Crude lysates of strains used for cross-reaction tests were obtained in a number of ways (extracting with phenol, boiling in SDS, homogenization by Bead-Beater, lysing by the Triton X100 protocol) to ensure that all possible epitopes were exposed for reaction with the antibodies, using $P$. stutzer $i$ (ATCC 14405) as a positive control, but only the very limited suite of reactions reported in Table 1 were observed. The small inhibition of enzyme activity due to antibody binding in some of the strains which react in Western blots implies that the epitopes responsible for the reaction are not within the active site or otherwise intimately involved in in vitro function of the enzyme.

Previous descriptions of antisera produced against purified nitrite reductase from $P$. stutzeri reported similar degrees of specificity. Korner et al. (1987) reported that anti-NiR antiserum from $P$. stutzeri (ATCC 14405) reacted only with $P$. stutzeri (ATCC 14405) and $P$. stutzeri (DSM 50227), but not with P. stutzeri (ATCC 17588) or any other pseudomonads tested, and concluded that the immunological cross reactivity or lack thereof was too specific to be useful as a phylogenetic indicator. Coyne et al. (1989) reported similar results for known denitrifying strains, although they were not reported in detail for the $P$. stutzeri JM300 antiserum. Coyne et al. (1989) also reported that the two NiR antisera, $P$. stutzeri JM300 and $P$. aeruginosa, did not produce identical immunological responses in the large suite of heterologous denitrifying strains which they tested. Our results are consistent in implying that there is greater immunological variability than indicated by comparisons of molecular mass of denatured protein or of position in gel assays of non-denatured protein.

The only cases in which reactivity with the NiR antiserum was detected in a strain other than known $P$. stutzeri strains were the isolates from the TMB intertidal mat. We suggest that these strains are probably similar to P. stutzeri (ATCC 14405), but that the outer cell proteins responsible for the IIF reaction are more variable in nature than the portion of the NiR protein for which our antiserum is specific. Variability in the $\mathrm{O}$-antigens of Gram-negative bacterial cells are used as the basis of strain distinction among otherwise indistinguishable strains of the same species, so it is not surprising that the IIF reaction (whole cell assay) is even more strainspecific than the NiR reaction.

The least specific, most functionally generic probe, is the $721 \mathrm{bp}$ fragment of the NiR structural gene. The fragment is $230 \mathrm{bp}$ downstream of the haem-binding region, a very highly conserved region with homologies in other haem-binding proteins (Jungst et al., 1991). The probe was designed to exclude the haem-binding region itself, but to include the region of sequence homology in the central portion of the NiR structural gene. Even at high stringency, the probe hybridized with many more denitrifying strains and isolates than did our NiR antiserum, and hybridized with every strain which reacted with the $\mathrm{NiR}$ antiserum. It appears that the probe does not universally correctly identify strains known to possess the $\mathrm{cd}_{1}$-type haem NiR, but it is more functionally specific than any of the NiR antisera described. For example, the NiR from Paracoccus denitrificans is reported to possess the haem $\mathrm{cd}_{1}$-type $\mathrm{NiR}$ (Miyata \& Mori, 1969), but does not hybridize with our probe (Table 1). Smith \& Tiedje (1992) found that a $1.2 \mathrm{~kb}$ probe including the carboxy terminus of the NiR gene hybridized with a few strains known to contain the Cu-type NiR, but not with strains which do not possess $\mathrm{NiR}$. The $721 \mathrm{bp}$ probe we used did not hybridize with 
any Cu-type NiR strains tested and did not hybridize with any non-denitrifying strains. Thiosphaera pantotropha and P. aureofaciens (Zumft et al., 1987) are both reported to possess the $\mathrm{Cu}$-type $\mathrm{NiR}$, and neither of these hybridized with our probe. Strains called Alcaligenes faecalis have been reported to possess either type of $\mathrm{NiR}$ (Coyne et al., 1989).

\section{Detection of NiR in natural samples}

The detection limit for IIF enumeration of $P$. stutzeri (ATCC 14405) in seawater was reported to be 20 cells $\mathrm{ml}^{-1}$ (Ward \& Cockcroft, 1993). Purified NiR was detected at levels equivalent to $2 \times 10^{4}$ cells, [or the number of $P$. stutzeri (ATCC 14405) cells in about $100 \mathrm{ml}$ of surface seawater; Ward \& Cockcroft, 1993]. $\mathrm{NiR}$ was extracted from and detected in dilutions of $P$. stutzeri (ATCC 14405) cells in samples representing $2 \times 10^{5}$ cells, approximately the number present in 1-10 1 of natural seawater. The amount of NiR enzyme present in cells in the environment is likely to be quite variable due to its inducible nature, so it is perhaps more meaningful to establish a detection limit in terms of number of enzyme molecules rather than numbers of cells. This detection limit corresponds to $2.5 \mathrm{ng}$ protein or approximately $10^{16} \mathrm{NiR}$ molecules (assuming two subunits of $66 \mathrm{kDa}$ per molecule). The amount of $\mathrm{NiR}$ protein in the seawater we sampled was apparently below this level. The environmental conditions in our samples were not likely to be suitable for induction of denitrification (fairly well oxygenated deep ocean water in a fairly oligotrophic area). Further sampling will be necessary to test our detection in natural samples.

The fact that the $721 \mathrm{bp}$ NiR DNA probe hybridized with undescribed isolates from both seawater and marine sediment environments implies that this type of $\mathrm{NiR}$ is prevalent at least among culturable denitrifiers from the marine environment. It is also detectable in unamended seawater, indicating that cells possessing this gene are present in natural populations at not insignificant levels. The slots in Fig. $5 c$ each represent the DNA from $500 \mathrm{ml}$ seawater. Thus, the estimated minimum number of target cells present, for example in the samples from depths of $160 \mathrm{~m}$ and deeper, was about $8.5 \times 10^{5} \mathrm{I}^{-1}$. In the surface sample, the signal appears to be much stronger, well above the limit of detection. A 10 -fold higher NiR gene abundance in shallow samples would correspond to the presence of $8.5 \times 10^{6}$ cells $1^{-1}$. Quantification and greater sensitivity will be possible using fluorescent substrates for alkaline phosphatase and quantitative hybridization methods (Kerkhof, 1992).

The only other estimate of denitrifier abundance, which does not derive from enrichment culture methods, is our previous enumeration of $P$. stutzeri (ATCC 14405) in Monterey Bay waters using IIF (Ward \& Cockcroft, 1993). P. stutzeri (ATCC 14405) abundances were of the order $2 \times 10^{4}$ (deep samples) to $2 \times 10^{5}$ (surface water) cells $1^{-1}$. Thus $P$. stutzeri (ATCC 14405), as detected by a strain-specific immunofluorescence assay, represents in the order of $2-3 \%$ of the denitrifier genomes which possess homology with its NiR gene.

Total bacterial abundance in the region from which the samples of $\mathrm{NiR}$ gene detection were collected has been estimated by epifluorescence direct counts at between $10^{8}$ and $10^{9}$ cells $1^{-1}$ in surface water and between $10^{7}$ and $10^{8}$ cells $1^{-1}$ below the photic zone (Ward \& Kilpatrick, 1993). Thus, our hybridization results imply that in the order of $1-10$ cells in 1000 of the total population has denitrification potential (i.e. homology with the $\mathrm{NiR}$ gene, a minimum estimate), whilst the immunofluorescence data indicate that 2 in 10000 of the total could be classified as a single strain of denitrifying bacteria. These comparisons are an indication of the scale of diversity that might be found in natural bacterial assemblages. Is the denitrifying assemblage composed of 10 different strains equally represented, or of many strains unequally represented, or of one dominant and many minor members? The comparison made here is limited by the necessity to culture organisms in order to develop the immunofluorescent probe for whole cell enumeration. Culturable organisms may be unrepresentative and thus very minor members of the natural community. Nevertheless, this comparison demonstrates the utility of multiple methods for characterization of natural bacterial assemblages.

\section{References}

ANSORGE, W. (1985). Fast and sensitive detection of proteins and DNA bands by treatment with $\mathrm{KMnO}_{4}$. Journal of Biochemical and Biophysical Methods 11, 13-20.

Ausubel, F. M., Brent, R., Kingston, R. E., Moore, D. D., Smith, J. A., Sideman, J, G. \& Struhl, K. (eds.). (1987). Current Protocols in Molecular Biology. New York: John Wiley \& Sons.

BeNDSChNeIDER, K. \& RobINSON, R. J. (1952). A new spectrophotometric method for the determination of nitrite in seawater. Journal of Marine Research 11, 87-96.

BIEBL, H. \& PFENNIG, N. (1978). Growth yields of green sulfur bacteria in mixed cultures with sulfur and sulfate reducing bacteria. Archives of Microbiology 117, 9-16.

BRADFORd, M. M. (1976). A rapid and sensitive method for the quantitation of microgram quantities of protein utilizing the principle of protein-dye binding. Analytical Biochemistry 72, 248-254.

Bryan, B. A. (1981). Physiology and biochemistry of denitrification. In Denitrification, Nitrification and Atmospheric Nitrous Oxide, pp. 67-84. Edited by C. C. Delwhich. New York: J. Wiley \& Sons.

Campbell, L., Carpenter, E. J. \& Iacono, V. J. (1983). Identification and enumeration of marine chroococcoid cyanobacteria by immunofluorescence. Applied and Enwironmental Microbiology 46, 553-559.

Carlucci, A. F. \& Pramer, D. (1957). Factors influencing the plate method for determining abundance of bacteria in sea water. Proceedings of the Society for Experimental Biology and Medicine 96, 392-394.

Coyne, M. S., Arunakumari, A., Averill, B. A. \& Tiedje, J. M. (1989). Immunological identification and distribution of dissimi- 
latory heme $c d_{1}$ and nonheme copper nitrite reductases in denitrifying bacteria. Applied and Environmental Microbiology 55, 2924-2931.

DAHLE, A. B. \& LAAKE, M. (1982). Diversity dynamics of marine bacteria studied by immunofluorescent staining on membrane filters. Applied and Environmental Microbiology 43, 169-176.

Gamble, T. N., Betlach, M. \& Tiedje, J. M. (1977). Numerically dominant denitrifying bacteria from world soils. Applied and Environmental Microbiology 33, 926-939.

JAHNKE, R. A. (1990). Early diagenesis and recycling of biogenic debris at the seafloor, Santa Monica Basin, California. Deep-Sea Research 48, 413-436.

JOYE, S. B. \& PAERL, H. W. (1993). Nitrogen fixation and denitrification in the intertidal and subtidal environment of Tomales Bay, California. In The Biogeochemistry of Global Change. Radioactively Active Trace Gases, pp. 633-653. Edited by R. S. Oremland. New York: Chapman \& Hall.

Jungst, A., Wakabayashi, S., Matsubara, H. \& Zumft, W. G. (1991). The nirSTBM region coding for cytochrome $c d_{1}$ dependent nitrite respiration of Pseudomonas stutzeri consists of a cluster of mono-, di- and tetraheme proteins. FEBS Letters 279, 205-209.

KERKHOF, L. J. (1992). A comparison of substrates for quantifying the signal from a nonradiolabeled DNA probe. Analytical Biochemistry 205, 359-364.

KORNER, H. \& ZUMFT, W. G. (1989). Expression of denitrification enzymes in response to the dissolved oxygen level and respiratory substrate in continuous culture of Pseudomonas stutzeri. Applied and Environmental Microbiology 55, 1670-1676.

Korner, H., Frunzke, K., Dohler, K. \& Zumft, W. G. (1987), Immunochemical patterns of distribution of nitrous oxide reductase and nitrite reductase (cytochrome $c d_{1}$ ) among denitrifying pseudomonads. Archives of Microbiology 148, 21-24.

Mryata, M. \& MoRI, T. (1969). Studies on denitrification. X. The 'denitrifying enzymes' as nitrite reductase and the electron system for denitrification. Journal of Biochemistry 66, 463-471.

PoRTer, K. G. \& Feig, Y. S. (1980). The use of DAPI for identifying and counting aquatic microflora. Limnology and Oceanography 25, 943-948.

Romling, U., Grontheus, D., Bautsch, A. W. \& TummLer, B. (1989).
A physical genome map of Pseudomonas aeruginosa PAQ. EMBO Journal 8, 4081-4089.

SCHMIDT, E. L., BANKOLE, R. O. \& BoHLOOL, B. B. (1968). Fluorescentantibody approach to study of rhizobia in soil. Journal of Bacteriology 95, 1987-1992.

SMITH, G. B. \& TIEDJE, J. M. (1992). Isolation and characterization of a nitrite reductase gene and its use as a probe for denitrifying bacteria. Applied and Environmental Microbiology 58, 376-384.

Southern, E. M. (1975). Detection of specific sequences among DNA fragments separated by gel electrophoresis. Journal of Molecular Biology 98, 503-517.

Sylvestrini, M. C., Galeotti, C. L., Gervais, M., Schinina, E., Barra, D., Bossa, F. \& BRUNori, M. (1989). Nitrite reductase from Pseudomonas aeruginosa: sequence of the gene and the protein. FEBS Letters 254, 33-38.

Towbin, H., Staeheln, T. \& Gordon, J. (1979). Electrophoretic transfer of proteins from polyacrylamide gels to nitrocellulose sheets: procedure and some applications. Proceedings of the National Academy of Sciences of the United States of America 76, 4350-4354.

WARD, B. B. \& CARLuCCI, A. F. (1985). Marine ammonia- and nitriteoxidizing bacteria: serological diversity determined by immunofluorescence in culture and in the environment. Applied and Environmental Microbiology 50, 194-201.

WARD, B. B. \& COCKCROFT, A. R. (1993). Immunofluorescence detection of denitrifying bacteria in seawater and intertidal sediment environments. Microbial Ecology 25, (in the Press).

WaRD, B. B. \& KilPatrick, K. A. (1993). Methane oxidation associated with mid-depth methane maxima in the Southern California Bight. Continental Shelf Research (in the Press).

Zobeli, C. E. \& Upham, H. C. (1944). A list of marine bacteria including description of sixty new species. Scripps Institute of Oceanography Bulletin 5, 239-292.

Zumft, W. G., Gotzmann, D. J. \& Kroneck, P. M. H. (1987). Type 1, blue copper proteins constitute a respiratory nitrite-reducing system in Pseudomonas aureofaciens. European Journal of Biochemistry 168, 301-307.

Zumft, W. G., Dohler, K., Korner, H., LOChelt, S., Viebrock, A. \& FRUNZKE, K. (1988). Defects in cytochrome $c d_{1}$-dependent nitrite respiration of transposon Tn5-induced mutants from Pseudomonas stutzeri. Archives of Microbiology 149, 492-498. 